\title{
Facilitators of the transition process for the self-care of the person with stoma: subsidies for Nursing*
}

\author{
Facilitadores do processo de transição para o autocuidado da \\ pessoa com estoma: subsídios para enfermagem \\ Facilitadores del proceso de transición para el autocuidado de \\ la persona con estoma: subsidios para la Enfermería
}

Marina Soares Mota ${ }^{1}$, Giovana Calcagno Gomes², Vilma Madalosso Petuco ${ }^{3}$, Rita Maria Heck Edaiane Joana Lima Barros ${ }^{5}$, Vera Lúcia de Oliveira Gomes ${ }^{6}$

\author{
* Extracted from the master's thesis "Transition \\ process of the person with a stoma from care \\ dependency to self-care: subsidies for nursing", \\ School of Nursing, Universidade Federal do Rio \\ Grande, 2014. \\ ${ }^{1}$ Master in Nursing, School of Nursing, \\ Universidade Federal do Rio Grande, Rio Grande, \\ RS, Brazil. \\ ${ }^{2}$ Adjunct Professor, School of Nursing, \\ Universidade Federal do Rio Grande, Rio Grande, \\ RS, Brazil \\ ${ }^{3}$ Professor, Institute of Biological Sciences, \\ Universidade de Passo Fundo, Passo Fundo, RS, \\ Brazil. \\ ${ }^{4}$ Associate Professor, Postagraduate Program, \\ Universidade Federal de Pelotas, Pelotas, RS, \\ Brazil. \\ ${ }^{5}$ Nurse Coordinator, Sector of Continuing \\ Education, University Hospital Dr. Miguel Riet \\ Jr., Rio Grande, RS, Brazil. ${ }^{6}$ Professora Titular, \\ Escola de Enfermagem, Universidade Federal do \\ Rio Grande, Rio Grande, RS, Brasil. \\ ${ }^{6}$ Professor, School of Nursing, Universidade
} Federal do Rio Grande, Rio Grande, RS, Brazil.

\begin{abstract}
Objective: To know the facilitating factors of the transition process from dependency to the self-care of people with a stoma. Method: This is a descriptive study of qualitative approach, including 27 people with permanent stomas due to cancer. The data were collected through semi-structured interviews and submitted to content analysis based on the Transition Theory as theoretical reference. Results: The self-care facilitators related to the person were the positive significance of ostomy; the preparation for this experience already in the preoperative period; emotional stability; faith; religiousness; and a sense of normalcy acquired from a next image similar to the previous one. The facilitators related to the community were the following: receiving equipment for free from the government; support from family and the multidisciplinary team, especially the nurses; and having contact with other people with stomata. Conclusion: The results allow that nurses develop strategies to help people with stomata to resume their self-care.
\end{abstract}

\section{DESCRIPTORS}

Ostomy; Self-care; Nursing Theory; Nursing Care. 


\section{INTRODUCTION}

Ostomy is a surgical procedure in which there is the externalization of a hollow organ such as the intestine or bladder, through a hole in the abdomen called stoma ${ }^{(1)}$. This procedure is carried out to maintain the function of elimination and causes various changes that may negatively affect the physical, psychological, social and sexual health of people who have to live with this condition of life $\mathrm{f}^{(2-3)}$. The presence of a stoma generates dependency of the collector bag of feces or urine.

Surgery may change the way people perceive themselves, turning them into someone different. Individuals may feel stigmatized by the presence of the stoma, and choose isolation as a form of hiding their bodies, now dependent on equipment and without sphincter control ${ }^{(4)}$.

In the process of living, people with stomata present difficulties to resume their daily activities, resulting in decreased quality of life. There may also be difficulties related to self-care, body image, sexuality, modes of dressing and interpersonal relations ${ }^{(5)}$. The life changes range from accepting the new condition until the need to adapt to new materials and knowledge, requiring the acquisition of skills and competencies for self-care. In this process, the person with a stoma goes through a transition.

According to Meleis' Theory of Transition ${ }^{(6)}$, 'each transformation period corresponds to significant moments of life, requiring that people develop new behaviors in the different contexts in which they operate, redefining their self(7), and promoting changes in their state of health, relationships, expectations and skills ${ }^{(8)}$. Simply put, the transition is divided into phases, namely: entrance, passage and exit $^{(9)}$. The transition process is completed when the person regains stability displayed by indicators, such as subjective well-being in the relationships, and the satisfactory development of their social roles ${ }^{(10)}$.

This theory is based on four key concepts, which are characterized as follows: nature (type, patterns and properties of transition), the transition conditions (process facilitators or inhibitors and related to the person, the community and society), patterns of response (process indicators and outcome of the transition, conductors of the Nursing therapeutics) $)^{(6)}$ and the own therapeutic interventions in Nursing ${ }^{(9)}$.

The type of transition can be divided into developmental (changes of the life cycle), situational (change of roles), health/illness (change from a healthy condition to an illness condition) and organizational (change in the social, political and/or economic environment $)^{(7)}$. The patterns of response are separated into process indicators displayed by the feeling of connection, interaction, of being located and developing confidence and coping, and by outcome indicators expressed in mastery/expertise in new skills and reformulation of fluid identities/integration. The mastery refers to the achievement of a positive and healthy result, from the experiences of the transition process ${ }^{(6)}$.

The therapeutic Nursing interventions interact with all the presented issues, and such interventions enable that nurses determine the best strategy for maintaining and promoting people's health ${ }^{(7)}$.
The conditions facilitating the transition covered in this study may help nurses to motivate people in transition towards their well-being and to reduce the risks of the difficult experience of the process ${ }^{(10)}$. These conditions are factors that promote the independence of care, from issues of the own person with ostomy, used by nurses as key points in the contextual therapeutic intervention, aimed at improving the patient's quality of life. Thus, the aim of this study is knowing the facilitators of the transition process from dependency to the self-care of the person with a stoma.

\section{METHOD}

This is a descriptive study of qualitative nature, carried out in the Stomatherapy service of a university hospital in southern Brazil. It is a medium-sized university hospital with 205 beds and serves as a training field for technical courses, as well as undergraduate and postgraduate courses the region. The Stomatherapy Service attends about 100 people with stomata and their families, through nursing consultations and group therapies. (atende 100 pessoas/dia? "atendeu" será q o serviço não existe mais?)

The inclusion criteria were the following: patients registered in the Stomatherapy Service, with a permanent stoma for more than a month by cancer of the genitourinary and/ or intestinal system, and with good health. People with inactive stomata in the Stomatherapy Service, those with recent stomata (less than a month), with stomata for reasons other than cancer of the genitourinary and/or intestinal system, and in a bad state of health were excluded.

The study included 27 people, of which 16 were men, aged between 33 and 77 years. The time with a stoma ranged from two months to 11 years. Regarding the type of stoma, 13 had colostomies, seven ileostomies and seven urostomies. The most recurrent cause of stoma was adenocarcinoma of the colon and rectum $(n=20)$ and bladder carcinoma $(n=$ 7). The level of education varied among incomplete elementary school $(n=8)$, complete elementary school $(n=11)$, complete high school $(\mathrm{n}=6)$ and Higher Education $(\mathrm{n}=$ 2). Thirteen patients were retired, 12 were unemployed and two worked in general services.

Data were collected in the first half of 2014 through semi-structured interviews ${ }^{(11)}$ with the following guiding question: What factors facilitate/inhibit the performance of selfcare? Individual interviews were conducted in the office of Stomatherapy Service, recorded and transcribed.

The data were submitted to content analysis ${ }^{(12)}$, which consists of the following: pre-analysis with the initial reading of data and drafting of the recording units; exploration of the material, in which the data are organized into categories; and treatment of results, inference and interpretation, by assigning meanings to the data.

The analysis was supported by scholar authors of the thematic and by the concepts of Afaf Meleis'Transitions Theory ${ }^{(6)}$, which allow understanding the transition processes and their facilitating or inhibiting conditions of people, the community and society, ensuring the development of contextualized actions, in order that such people reach the stability of their health and a sense of well-being. 
The study followed the national and international standards of ethics in research with human beings and was approved by the Ethics Committee of the Universidade Federal do Rio Grande under number 002/2014. People with stomata, who met the inclusion criteria were invited to participate in the study voluntarily.

\section{RESULTS}

Based on the adopted theory, the data analysis generated the following categories: Conditions related to the person and Conditions related to the community.

\section{Conditions Related to the PERSON}

The self-care can be facilitated by establishing strategies based on conditions related to the person. Thus, the stoma gains a positive meaning when it is seen as the person's possibility of living after surgery.

\section{I adapted because I wanted to live. Nowadays, being a person with a stoma means being a per- son who suffered a mutilation, but who gradu- ally adapts to being a normal person again (P3).}

Being prepared or not for the experience of ostomy and its modifications may influence the performance of self-care. People with stomata realize the need to receive guidance about their self-care and the changes in living already in the peroperative period, preparing them for what will come. The preparation helps in acquiring skills for self-care by enabling awareness of what awaits them after surgery.

\section{Before undergoing surgery, I had no idea of what they would really do with me and about the care I would have to take. So I went to the Stoma- therapy Service and I even learned to how to feed myself, what bag to use. Several things that facilitated my life afterwards! (P15).}

Some people omit the fact that they have a stoma from the society for fear of rejection attitudes. Although this seems a form of denial, it allows some time for people to feel stronger and able to expose themselves to others.
It's the same thing. I know I use it, but many pe- ople don't even know because I don't tell anyone. The clothes hide it. Today I feel good! I even tell some people (P12).

The person with stoma recognizes the importance of having psychological stability for self-care and accepting the new situation of life, which is understood as a difficult process due to the characteristics of an ostomy.

\section{If people don't have a good head on their shoul- ders, they won't adapt and take care of them- selves! Because it is hard to think how will one adapt to something that was not born with them, full of poop, that stinks and that leaves everyone disgusted with them (P9).}

Faith and religion are allies in the transition process to the extent that they bring comfort and make people with a stoma more centered and focused on their process of care and health.
I am very religious. I didn't die because the man up there didn't want me to. So I thank Him every day. He gives me strength to be normal $\operatorname{again}(\mathrm{P} 4)$.

I have always been a Catholic, but after the sur-
gery I started going to the spiritist center and
it helped me a lot, gave me a lot of faith (P10).

\section{Conditions Related tO THE COMMUnity}

The free supply of equipment by the Health Department, upon registration with the Stomatherapy service in the nursing consultations is a facilitator of the process. It guarantees that patients will receive their equipment without the need for a journey in search of care.
I was so afraid to be without supply of the bag, but not today, because I come here, talk to the nurse and she sorts it out. At first, I also received via Porto Alegre in a health unit. After I started here, I never went there again to get it, and it's much better (P4).

The Stomatherapy Service has a multidisciplinary team with nurses who carry out nursing consultations and hospital or home visits. They also work with the support group for people with ostomy and their families, for developing therapeutic interventions to assist in the acquisition of knowledge and skills for self-care.

I wouldn't change my bag. Then I came to a
meeting with the nurse, who asked me why I
wouldn't change. And I said: - "Cause I can't do
it. I have my daughter-in-law and my daughter
who change it". She said: - "Will you always de-
pend on your partner or your daughter-in-law
to change it? Here's what you'll do: when you
see that the bag will unstick, you wake up in the
morning, do your personal hygiene and change the
bag. There won't be much liquid to clean and you'll
be able to change it". It changed my life! Now I
go, I carry my bag in the purse and it's fine (P14).

The interdisciplinary team appears as a facilitator of the transition process towards the acquisition of selfcare, visualizing people with a stoma as a whole, helping to resolve issues that promote their health, making them autonomous.

$$
\begin{aligned}
& \text { In the Stomatherapy Service, we have support. } \\
& \text { We know that the professionals will always be } \\
& \text { there to help us. They give us a great of confidence } \\
& \text { that we can live well and be autonomous! (P20). }
\end{aligned}
$$

The first moments after the ostomy are difficult. The family is the support that provides care initially, then gradually delegating it to people, making them stronger for performing self-care.

$$
\begin{aligned}
& \text { At first, my husband used to come with me to the } \\
& \text { consultations, then I started coming alone. He }
\end{aligned}
$$


helped me to take care of the stoma and later on,

I never depended on anyone again (P14).

When supporting people with stoma in difficult times, the family makes them feel secure and that they will have help to overcome all the complicated moments and even the embarrassing ones as, for example, the leakage of the collection bag outside the home.

It is difficult when the bag leaks in parties or family gatherings, but thankfully my kid has a motorcycle! When it happens, I call him on the corner so the other people won't see and I tell what's happened and he takes me away (P8).

By offering help in the care and showing physical affection, the family becomes closer to people with stoma, fostering a sense of belonging and support, and also helping them to perform their self-care activities.

The older daughter even changed. She said: - "Do you want me to change? Lie down and I'll change it". Especially in this time of heat. She turned on the fan for me. Took the hair dryer and heated the pad, as I do for better adherence of the pad. But only that. I never failed to do anything but I accept a little belp sometimes (P11).

When the partners understand the changes brought by the ostomy and the periods of emotional instability, they help with developing support strategies for the emotional and physical care, motivating the person with a stoma to live healthily and autonomously.

\section{Of course, it is hard to look at, but I'm lucky to have a partner who lived this whole situation together. We are overcoming it. My husband was able to accept it (P4).}

For some people with stomata, initially, it may be difficult to picture a full life using the collection bag. Thus, it is important to talk to other people with stomata, which helps in understanding what is going on with their own lives. People with stoma who have already adapted to it also feel stronger by showing others that it is possible live well and autonomously.

I adapted. I was well. I lost count of how many times the nurse of the Stomatherapy Service has called asking me to talk to patients who were having acceptance problems or were going to put the collecting bag. The doctors too, when they are going to operate someone, they ask me to go and talk to the patient. It's allright, thank God (P11).

In addition to individual discussions, the fact of integrating a support group in the Stomatherapy Service provides the interaction of people with stoma by sharing experiences, which facilitates self-care and shows that they are not alone in this journey. That it is possible to care for themselves and live with quality.

The group is good because we see that it's not just us. Just the fact of being there passes good things for others! Not everyone has the same courage

(...). We talk and when there's nothing to say, you listen to others! You always learn new things (P27).

\section{DISCUSSION}

The transition can start with enchantment and excitement or with fear and grief. The process is between what happened before and what is evolving. The transition can promote qualification and growth, representing a crucial time to enable and support the development and resilience ${ }^{(8)}$.

The conditions of transitions include meanings, expectations, level of knowledge and skill, environment, level of planning and of the physical and emotional well-being ${ }^{(10)}$. The results of this study indicate conditions that facilitate self-care related to the person, such as building a positive meaning for the ostomy, the preparation for this experience already in the preoperative period, the emotional stability, faith, religion, and a sense of normality acquired from an image similar the previous one.

The changes in health status can promote well-being, expose people to increased risks of disease and also trigger a transition process ${ }^{(6)}$. Regarding the conditions related to the person within this process, it is noticeable that the creation of a concept or a positive image of the surgery can facilitate the acquisition of self-care.

The ostomy surgery is a moment of significant transition in the lives of people who seek to adapt to this new condition because of their will to go on living. The ostomy enables the continuity of their lives and, therefore, can be viewed positively, as part of the resolution of the health problem and a second chance to live ${ }^{(5)}$.

Transition is an individual phenomenon without a defined structure, considering that the subjectivity and the meanings involved can be attributed to different times of transition that vary according to the experiences, reflections and culture, in other words, the personal characteristics. The transition processes interact with the (re)definitions of oneself and from the transitional situation originated in the person experiencing them ${ }^{(9)}$.

It was observed that the preparation for this experience, even preoperatively, facilitates the transition process and reduces the impact of the event, allowing the confrontation and the development of strategies to assist in self-care ${ }^{(6)}$. The physical and psychological dimensions may be affected by the lack of guidance in the preoperative period, making it difficult to face the postoperative period ${ }^{(13)}$.

The ostomy surgery can negatively impact the lives of people with stoma, generating feelings of emotional clutter and hindering the exercise of self-care ${ }^{(14)}$. Instability can arise due to the dramatic change in lifestyle, bringing physiological and psychological damages due to problems related to the stoma ${ }^{(15)}$. However, this study showed the stability of people in transition to self-care as a facilitating condition, which allows understanding the need to search for knowledge that qualifies their actions. 
The spiritual well-being can be modified after the stoma ${ }^{(16)}$. This fact was evidenced in the speeches of participants who reported faith and religiosity as conditions related to the person. Having faith facilitates the transition process when comforting the people, by directing their force towards health and autonomy, helping in the reflection about living and enabling the resignification of life ${ }^{(17)}$.

The image modified by the stoma produces the need of readjusting the physical appearance ${ }^{(18)}$. Thus, people tend to want to omit their stoma, and to do so, they need to develop forms of self-care ${ }^{(14)}$. A sense of normality results from an image similar to the one before surgery, and is a facilitating condition related to the person. Moreover, omitting the stoma provides the time that patients need for feeling secure and learning the self-care ${ }^{(19)}$.

The processes of transition may involve one or more individuals in a given context and situation, and the transition features include the process, the perception of change and the response patterns of those included ${ }^{(9)}$. As social beings, the relations between people and community can promote the advancement of transition phases because such relations can assist in strengthening self-care.

The following facilitating conditions related to the community were mentioned: family support, the free supply of equipment for self-care (such as collecting bags and adjuvants) by the Health Department, plus access to a reference space in specialized care, such as the Stomatherapy service with consultations with nurses and other professionals. Such conditions facilitate the transition because they prevent that people with stoma have to go through a difficult journey in search of care.

In developing countries, acquiring the equipments is generally difficult, since they are imported and expensive. Hence, the challenge is great for those without access to materials through governmental programs. Often, families cannot buy such materials without public funding ${ }^{(20)}$.

In Brazil, the National Guidelines for the Health Care of People with Stomata in the Unified Health System (SUS - Sistema Único de Saúde) ensure the comprehensive health care of people with stoma, which includes the supply of materials that favor self-care ${ }^{(1)}$. Receiving the material for self-care does not mean the person will easily adapt to it, or that it will have the expected durability. It is important that the person with stoma has access to good quality products that bring security, comfort and discretion ${ }^{(21)}$.

In addition to the subsidy of equipment, it was observed that the multidisciplinary care is a transition condition related to the community. This is due to the fact that Stomatherapy services help people with stoma to achieve autonomy through educational workshops and groups of exchange of experience, among others ${ }^{(22)}$. The interdisciplinary care is provided through Ordinance number SAS/MS 400 , of November $16^{\text {th }}, 2009$, which establishes the basic composition of Stomatherapy services ${ }^{(1)}$.

The nurses make up the team that treats people with stomata aiming at their health through self-care. Within the context of the acquisition of self-care, nurses are the transforming agents who act as educators of people with stomata and their families by using educational technologies that facilitate the attainment of knowledge ${ }^{(23-24)}$, by intervening in problems arising from ostomy and facilitating the transition process to the acquisition of self-care. These professionals can use methods of health promotion to help people with stomata dealing with problems or the inhibitors conditions of the transition process, providing ongoing guidance $^{(2-3)}$. The Transition Theory, interconnected with the reality of Nursing, aims to guide the actions that result in nursing $\operatorname{care}^{(7)}$.

The experience of ostomy is a difficult process, permeated by fear, embarrassment, discomfort and doubts, in which the family help is essential to support and empower the person to regain their autonomy, resignify their identity and improve their self-esteem and social reinsertion ${ }^{(25)}$. Often, family and friends take care of the person with a stoma. However, if they continue to do so for a long time, they can inhibit the transition to self-care, because the person may not become autonomous, but insecure and dependent ${ }^{(26)}$.

Most of the time, the family starts performing the stoma care and gradually passes on this task to the person with stoma, in a process of sharing the care actions, respecting their limits and their independence, within their possibilities, a fact that promotes self-esteem and a new autonomous identity ${ }^{(25-27)}$. As the family is present in everyday life of people with stoma, their support in coping with the transition, aiming at self-care, is a major condition related to the community, helping to minimize their difficulties.

The difficulties of maintaining the collection bag and the embarrassment with the odor and gases may discourage the person with stoma, leading to isolation and dependence. The help of family and friends, and the affection and attention in those moments can be of great help ${ }^{(28)}$. In the family nucleus, the partners or spouses are important collaborators of the transition. In order to develop this role, they need to be supported to care for the person with stoma ${ }^{(18)}$, since they may also be going through difficult times.

Besides family support, the people with stoma need other ways to feel part of society. The contact with other people with stomata who have been through the same experiences, allows to foresee the possibility of living well and autonomously. The interaction with people in similar situations facilitates treatment compliance and acceptance of the new life condition ${ }^{(15)}$.

The family is the core of social interaction, however, when people with stoma join a support group, they are able to broaden their vision of the possibilities of living independently. This fact transforms the support group into a major facilitating condition related to the community.

Support groups provide interaction, helping people to share experiences and pass phases more quickly and in a less traumatic way. In these group activities, there is strengthening to cope with everyday difficulties, which helps to improve acceptance and the quality of life of people with stomata ${ }^{(22)}$. The groups that develop planned interventions are an effective strategy of social support ${ }^{(29)}$, providing a space of coexistence in an educational environment of information supply related to the life context of people with stomata ${ }^{(23)}$. 
The support of family, friends, work, religion and other patients to people with stoma is a facilitator of the transition process. This is an important form of motivation to overcome adversities $^{(30)}$, through which people can see that it is possible to live healthily with the stoma, inserted in the social environment and surrounded by friends ${ }^{(14)}$. Feeling safe and supported, people with stoma can fully perform self-care, what is important for them ${ }^{(25)}$.

The transition requires changes in health status, relationships, roles, expectations and skills of people ${ }^{(8)}$. Thus, based on the theoretical knowledge of the Transition Theory, the nurses may establish actions subsidized in their individual reflection, to understand the process by intervening in the physical and mental dimensions. Such interventions guide the person, the family and community for the promotion and recovery of health or disease prevention. The prescribed care prevents risks and detects problems, solving them or reducing their impact.

\section{CONCLUSION}

The study allowed identifying the conditions of the transition process from dependency to the acquisition of self-care of people with a stoma according to the Transition Theory of Afaf Meleis. The facilitating factors of the transition process as conditions related to people were the following: to attribute a positive meaning to the stoma; receive guidance on the care of the stoma and the changes in living, with the preparation for this experience already preoperatively; show psychological stability; and seek comfort in faith and religiosity. The community-related conditions were the following: receiving equipment for free from the government; the support of family and the multidisciplinary team, especially the nurses; and having contact with other people with stomata.

The study data allow to conclude that the transition to self-care is complex, full of subjectivities and difficulties, and the interactions with family, friends and health services can assist in the recovery of autonomy. These conditioning factors enable to direct therapeutic nursing interventions that are effective and efficient for the (re)development of skills and abilities for self-care, resulting in an independent and healthy living.

The fact that this study was performed in a single context can be a limitation.

\section{RESUMO}

Objetivo: Conhecer os fatores facilitadores do processo de transição da dependência para o autocuidado da pessoa com um estoma. Método: Pesquisa descritiva, com abordagem qualitativa, incluindo 27 pessoas com estomas definitivos por câncer. Os dados foram coletados através de entrevista semiestruturada e submetidos à análise de conteúdo utilizando como referencial teórico a Teoria das Transições. Resultados: Verificaram-se como facilitadores do autocuidado relacionados à pessoa, a significação positiva da estomização; o preparo para essa experiência ainda no pré-operatório; a estabilidade emocional; a fé; a religiosidade; e a sensação de normalidade adquirida a partir de uma imagem próxima da anterior. Como facilitadores relacionados à comunidade, foram encontrados: receber equipamentos pelo Governo de forma gratuita; apoio da família e da equipe multiprofissional, em especial do enfermeiro; e contato com outras pessoas com estomas. Conclusão: Esses resultados permitem que o enfermeiro desenvolva estratégias para auxiliar a pessoa com estoma a retomar seu autocuidado.

\section{DESCRITORES}

Estomia; Autocuidado; Teoria de Enfermagem; Cuidados de Enfermagem.

\section{RESUMEN}

Objetivo: Conocer los factores facilitadores del proceso de transición de la dependencia para el autocuidado de la persona con estoma. Método: Investigación descriptiva, con abordaje cualitativo, incluyéndose a 27 personas con ostomías definitivas por cáncer. Los datos fueron recogidos mediante entrevista semiestructurada y sometidos al análisis de contenido utilizando como marco de referencia teórico la Teoría de las Transiciones. Resultados: Se verificaron como facilitadores del autocuidado relacionados con la persona: la significación positiva de la estomización; la preparación para esa experiencia aún en el preoperatorio; la estabilidad emocional; la fe; la religiosidad; y la sensación de normalidad adquirida a partir de una imagen próxima de la anterior. Como facilitadores relacionados con la comunidad, se encontraron: recibir equipos del gobierno de forma gratuita; apoyo de la familia y del equipo multiprofesional, en especial del enfermero; y el contacto con otras personas estomizadas. Conclusión: Esos resultados permiten que el enfermero desarrolle estrategias para auxiliar a la persona con estoma a retomar su autocuidado.

\section{DESCRIPTORES}

Estomía; Autocuidado; Teoría de Enfermería; Atención de Enfermería.

\section{REFERENCES}

1. Brasil. Ministério da Saúde. Portaria n. 400 de 16 de novembro de 2009. Estabelecer Diretrizes Nacionais para a Atenção à Saúde das Pessoas Ostomizadas no âmbito do Sistema Único de Saúde -SUS, a serem observadas em todas as unidades federadas, respeitadas as competências das três esferas de gestão [Internet]. Brasília; 2009 [citado 2014 mar. 23]. Disponível em: http://bvsms.saude.gov.br/bvs/ saudelegis/sas/2009/prt0400_16_11_2009.html

2. Ang SG, Chen HC, Siah RJ, Ele HG, Klainin-Yobas P. Stressors relating to patient psychological health following stoma surgery: an integrated literature review. Oncol Fórum Enferm. 2013;40(6):587-94. 
3. Altschuler A, Ramirez M, Grant M, Wendel C, Hornbrook MC, Herrinton L, et al. The influence of husbands' or male partners' support on women's psychosocial adjustment to having an ostomy resulting from colorectal cancer. J Wound Ostomy Continence Nurs. 2009;36(3):299-305.

4. Danielsen AK, Soerensen EE, Burcharth K, Rosenberg J. Learning to live with a permanent intestinal ostomy: impact on everyday life and educational needs. J Wound Ostomy Continence Nurs. 2013;40(4):407-12.

5. Mota M, Gomes GC. Changes in the process of living of ostomized patients after surgery. Rev Enferm UFPE On Line [Internet]. 2013 [cited 2014 Mar 23];7(spe): 7074-81. Available from: http://www.revista.ufpe.br/revistaenfermagem/index.php/revista/article/view/3435/ pdf_4259

6. Meleis AI, Sawyer LM, Im EO, Hilfinger Messias DK, Schumacher K. Experiencing transitions: an emerging middle-range theory. ANS Adv Nurs Sci. 2000;23(1):12-28.

7. Meleis Al. Theoritical nursing: development and progress. 4th ed. Philadelphia: Lippincott William \& Wilkins; 2007.

8. Meleis Al. Transitons theory: middle-range and situation-specific theories in nursing research and practice. New York: Springer; 2010.

9. Chick N, Meleis Al. Transition: a nursing concern. In: Chinn PL, editor. Nursing research methodology. Boulder: Aspen; 1986. p. $237-57$.

10. Schumacher KL, Meleis AI. Transitions: a central concept in nursing Image J Nurs Sch. 1994;26(2):119-27.

11. Minayo MCS. Pesquisa social: teoria, método e criatividade. $29^{a}$ ed. Petrópolis: Vozes; 2010.

12. Bardin L. Análise de conteúdo. Lisboa: Edições 70; 2009.

13. Pereira APS, Cesarino CB, Martins MRI, Pinto MH, Netinho JG. Associations among socio-demographic and clinical factors and the quality of life of ostomized patients. Rev Latino Am Enfermagem. 2012;20(1):93-100.

14. Cheng F, Meng AF, Yang LF, Zhang YN. The correlation between ostomy knowledge and self-care ability with psychosocial adjustment in Chinese patients with a permanent colostomy: a descriptive study. Ostomy Wound Manage. 2013;59(7):35-8.

15. Kwiatt M, Kawata M. Avoidance and management of stomal complications. Clin Colon Rectal Surg. 2013;26(2):112-21.

16. Bulkley J, McMullen CK, Hornbrook MC, Grant M, Altschuler A, Wendel CS, et al. Spiritual well-being in long-term colorectal cancer survivors with ostomies. Psychooncology. 2013;22(11):2513-21.

17. Sousa CF, Brito DC, Branco MZPC. Depois da colostomia...vivências das pessoas portadoras. Enferm Foco [Internet]. 2012 [citado 2014 mar. 25];3(1):12-5. Disponível em: http://revista.portalcofen.gov.br/index.php/enfermagem/article/view/213

18. Danielsen AK. Life after stoma creation. Dan Med J. 2013;60(10):B4732.

19. Vieira LM, Ribeiro BNO, Gatti MAN, Simeão SFAP, Conti MHS, Vitta A. Câncer colorretal: entre o sofrimento e o repensar na vida. Saúde Debate. 2013;37(97):261-9.

20. Buckley BS, Gonzalez JP, Razon-Gonzalez, EV, Lopez MP. The people that the ostomy industry forgot. Br J Gen Pract. 2012;62(603):544-5.

21. Williams J. Selecting stoma care appliances and accessories. Nurs Resid Care. 2008;10(3):130-3.

22. Fernandes RM, Miguir ELB, Donoso TV. Perfil da clientela estomizada residente no município de Ponte Nova, Minas Gerais, Brasil. Rev Bras Coloproct. 2010;30(4):385-92.

23. Barros EJL, Santos SSC, Gomes GC, Erdmann AL. Gerontotecnologia educativa voltada ao idoso estomizado à luz da complexidade. Rev Gaúcha Enferm [Internet]. 2012 [citado 2014 mar. 25];33(2):95-101. Disponível em: http://seer.ufrgs.br/RevistaGauchadeEnfermagem/ article/view/16325

24. Mauricio VC, Souza NVDO, Lisboa MTL. O enfermeiro na reabilitação da pessoa com estoma. Escola Anna Nery Rev Enferm. $2013 ; 17(3): 416-22$.

25. Nascimento CMS, Trindade GLB, Luz MHBA, Santiago RF. Vivência do paciente estomizado: uma contribuição para a assistência de enfermagem. Texto Contexto Enferm. 2011;2(3):557-64.

26. Cetolin SF, Beltrame V, Cetolin SK, Presta AA. Social and family dynamic with patients with definitive intestinal ostomy. Arq Bras Cir Dig. $2013 ; 26(3): 170-2$

27. Weiland LA, Cazoli EA, Neuman ABT, Rosanelli CP, Loro MM, Kolankiewich AB. A família e seu ente colostomizado no domicílio. Rev Contexto Saúde. 2010;10(20):77-84.

28. Souza PCM, Costa VRM, Maruyama SAT, Costa ALRC, Rodrigues AEC, Navarro JP. As repercussões de viver com uma colostomia temporária nos corpos: individual, social e político. Rev Eletr Enferm [Internet]. 2011 [citado 2014 mar. 23];13(1):50-9. Disponível em: http://www. fen.ufg.br/fen_revista/v13/n1/v13n1a06.htm

29. Karabulut HK, Dinç L, Karadag A. Effects of planned group interactions on the social adaptation of individuals with an intestinal stoma: a quantitative study. J Clin Nurs. 2014;23(19-20):2800-13.

30. Cardoso DH, Muniz RM, Guimarães SRL, Viegas AC, Pinto DK, Laroque MF. Viver com câncer: a percepção de pacientes oncológicos. J Nurse Health. 2012;2(2):461-74. 